\title{
EFFECT OF AGRICUTURAL INSURANCE ON AGRICULTURE SECTOR IN NIGERIA
}

\author{
Chizoba P. Ehiogu' and Aneke Joseph ${ }^{2}$ \\ 1. Department of Insurance and Actuarial Science, Imo State University Owerri, Nigeria \\ 2. Coal City University, Enugu State, Nigeria
}

E-mail: chizzypep@gmail.com

\begin{abstract}
This study examines effect of agricultural insurance on the agriculture sector in Nigeria. Ex-post facto research design was used in the study. Analysis technique applied was Ordinary least square. It was found that agriculture insurance claims-paid have no significantly effect on the volume of credit to food stock sector; agriculture insurance reserves have no significantly effect on the volume of credit to food stock sector; agriculture insurance claims-paid have no significantly effect on the volume of credit to livestock sector; and agriculture insurance general reserves have no significantly influence on the volume of credit to livestock sector. Based on the findings of the study it was concluded that agriculture insurance has minimal influence on credit given to farmers. As such, agriculture insurance still has a long way to go to become relevant in the economy. It was recommended that pilot processes should be used to gradually grow farmers into participation in agricultural insurance. This will scale up farmers understanding of and trust in agricultural insurance.
\end{abstract}

Keywords: Agriculture, Farmers, Risk, Insurance

https://dx.doi.org/10.4314/jafs.v17i1.10

\section{INTRODUCTION}

In view of persistent and wide forms of risks facing their means of living farming households pursue several traditional means of overcoming these risks. For example, to reduce exposure to potential losses, farmers often spread their bets by growing a mix of crops and crop varieties, stagger crop planting dates, and spread crops amongst fields that have different risk exposures in the landscape. These techniques can help reduce the chance of a major crop loss in any one season. Many farm households also engage in off-farm employment, or have a non-farm business of their own, and these help to reduce their dependence on farm income. To cope with the losses that do occur, farmers carry stocks of food, livestock, savings and other assets that can be consumed or sold in times of need. They may also take credit and engage in temporary offfarm employment. Communities provide another layer of protection against risk (Bhattamishra and Barrett, 2010). Religious funds, credit groups, and kin support networks provide reciprocal 
means through which individuals can help each other in times of need. Sharecropping contracts also emerged in many societies as a way of sharing risks between landlords and tenants (Kuhn, 2016). In pastoral areas, reciprocal arrangements between spatially dispersed communities enable mobile or nomadic grazing practices that reduce the risk of livestock having insufficient forage in any one location (McCarthy, Swallow, Kirk and Hazell, 1999). Repeated income shocks and asset losses can conspire to keep poor households trapped in poverty (Kuhn, 2016). Considering the above, seeking insurance becomes imperative. Ogwo, Eche, Ibeabuchi, Nwite and Enwereuzo (2000) assert that any device aimed at reducing the chance of a risk occurring or when it happen reduces the extent of its damage and providing the affected person with compensation is a form of insurance. It has great potential to provide value to low-income farmers and their communities, both by protecting farmers when shocks occur and by encouraging greater investment in crops. Eze (2019) noted that the development of agriculture requires financial services that can support larger agriculture investments and agriculture-related infrastructure that require long-term funding (given that currently transportation and logistics costs are too high, especially for landlocked countries), a greater inclusion of youth and women in the sector, and advancements in technology (both in terms of mechanising the agricultural processes and leveraging mobile phones and electronic payment platforms to enhance access and reduce transaction costs).It further stated that agriculture finance and agricultural insurance are strategically important for eradicating extreme poverty and boosting shared prosperity.

In many countries, insurance sector contributes to economic growth both sectorally and geographically. Since insurance sector has links to other economic sectors such as industrial, transportation, agriculture, trade and others, both locally and internationally, its relevance to general human activities has continued to grow for all ages as all categories of risks increase (Zyka and Tomori, 2014). However, the ability of the insurance industry to contribute to the growth of an economy is dependent on its capacity. This is usually indicated by the level of development the industry has. Agriculture insurance in Nigeria has not received much patronage. It is growing at slower rate than provision of credit to the agriculture sector. This suggests that lending to the agriculture community in Nigeria does not build on the stability that available agriculture insurance in the economy provides. There are a number of factors necessitating this poor situation. Yet the situation can be seen differently. The non reliance on insurance paints a picture of many prospects of untapped market for agriculture insurance in Nigeria. Despite the existence of insurance services from Nigeria Agricultural Insurance Corporation and other private firms in Nigeria, there has been low level of participation in insurance activities by farmers. In view of this, there is need to determine feasibility of deepening the agriculture insurance market in Nigeria.

\section{Objectives of the Study}

The main objective of the study is to investigate the effect of agricultural insurance on agriculture sector in Nigeria. Its specific objectives are: 
I. To examine the extent to which agriculture insurance claims paid significantly affected credit to foodstock sector.

II. To assess the level to which agriculture insurance reserves significantly affected credit to foodstock sector.

III. To evaluate the degree to which agriculture insurance claims significantly affected credit to livestock sector.

IV. To ascertain the measure to which agriculture insurance reserves significantly affected credit to livestock sector.

\subsection{Hypotheses of the study}

The following null hypotheses were formulated for the study:

$\mathrm{H}_{0} 1$ : Agriculture insurance claims paid have no significantly effect on volume of credit to foodstock sector.

$\mathrm{H}_{0}$ 2: Agriculture insurance reserves have no significantly effect on the volume of credit to foodstock sector.

$\mathrm{H}_{0} 3$ : Agriculture insurance claims paid have no significantly effect on the volume of credit to livestock sector.

$\mathrm{H}_{0} 4$ : Agriculture insurance reserves have no significantly effect on the volume of credit to livestock sector.

\section{CONCEPTUAL REVIEW}

\subsection{Concept of Agricultural Insurance}

Agricultural Insurance is a valuable business risk management tool that provides farmers with financial protection against production losses caused by natural perils, such as drought, excessive moisture, hail, frost, wind and wildlife (Governments of New Brunswick, 2019). Agricultural insurance is the stabilization of income, employment, price and supplies of agricultural products by means of regular and deliberate saving and accumulation of fund in small installment by many in favorable time period to defend the participation in bad time (Mordi, 1995). There are three types of agents that are active in providing agricultural insurance: the private for profit sector, governments (public), and other, mostly nonprofits (mutual groups, NGOs, etc.). Other agencies help finance and initiate insurance programs, including bilateral donors, United Nations (UN) organizations, multinational development banks, private foundations, and international reinsurers, but they do not deliver insurance on the ground. Few economic groups have a greater need of insurance than do the farmers. This need embraces nearly all the forms of protection offered by fire, life, and casualty insurance companies. Insurance against fire and lightning is quite as necessary to the farmer as to the city man, while such coverage against windstorm is 
even more generally needed in the country than in the city (Valgren, 1930). Farm property is more exposed to wind, as well as to lightning, and, in the case of severe storms; the farm building is more subject to destruction. Farmers need accident insurance, the employer of labor on the farm needs liability insurance, as well as coverage for accidents occurring to him. Farmers needs live-stock and crop insurance.

\section{Challenges facing agriculture insurance in Nigeria}

Eze (2019) points out that the growth and deepening of agriculture finance markets is constrained by a variety of factors which include: inadequate or ineffective policies; high transaction costs to reach remote rural populations, covariance of production, market, and price risks; and absence of adequate instruments to manage risks; low levels of demand due to fragmentation and incipient development of value chains; and lack of expertise of financial institutions in managing agricultural loan portfolios."

Climate change poses significant risks to agricultural development and by extension, food security, poverty reduction and political stability, thereby threatening sustained economic growth, especially in Nigeria, where agriculture contributes over $40 \%$ of the GDP, over $70 \%$ of the workforce is engaged in agriculture related activities and millions residing in rural areas depend on agriculture for their livelihood (Hellin and Hansen, 2017). Climate risks, such as the drought that affected the north of Nigeria in 2013, often lead to farmers being reluctant to invest in their farms. Farmers also have limited access to credit and remain trapped in a low incomelow productivity cycle. The Bank of Agriculture (BOA) said on that it was on a recovery mission of disbursed funds to farmers, totalling over N60 billion. Kabirgave the figure at a workshop organised by the Agege Branch of the bank entitled "Enhancing Wealth Creation across the Agricultural Value Chains"'.

\section{Prospects of developing Agriculture insurance market in Nigeria}

Since September 2014, Federal Ministry of Agriculture and Rural Development (FMARD) and the Climate Change, Agriculture and Food Security research program (CCAFS) of the Consultative Group on International Agricultural Research (CGIAR) have been working together to design a roadmap for evidence-based insurance development for Nigeria's farmers. CCAFS organized an initial knowledge sharing workshop in London in January 2015. This was followed by a planning meeting in Zurich in May 2015, hosted by Swiss Re. Participants in the workshops included FMARD, the heads of the Nigerian and Indian Agricultural Insurance Corporations, CCAFS, Swiss Re, German Corporation for International Cooperation (GIZ), Nigerian Meteorological Agency (NIMET), Nigerian Agricultural Insurance Corporation (NAIC) and Nigerian Insurers' Association (NIA). Experiences from index insurance initiatives in India, Kenya, Rwanda, Ethiopia and Senegal suggest that there is demand for index insurance, and that bundling insurance with production inputs and finance can make insurance more attractive to farmers. Well-designed index insurance can achieve specific risk objectives such as protecting farmers' livelihoods in the face of major climate shocks, and promoting farmers' livelihoods by 
overcoming barriers to adoption of improved agricultural technologies and practices, and access to market opportunities.

\section{MATERIALS AND METHODS}

This research employed ex-post facto research design. Secondary data was used in the study. The data were taken from Central Bank of Nigeria Statistical Bulletin and Nigerian Agricultural Insurance Corporation financial reports. The period of the study was from 2005 to 2018. The base year of 2005 was from when Nigerian Agricultural Insurance Corporation could provide data on its financial activities as against 1987 when it was established. The Ordinary Least Squares (OLS) was used as a statistical test technique for the data analysis.

Decision Rule: Reject the null hypothesis where p-value is less than the level of significance ( 0.05 percent) and accept the alternative hypothesis. Where p-value is higher than 0.05 percent the null hypothesis is accepted.

\section{RESULTS}

The mean values of the respective variables are high showing that they do not aggregate easily. The median values of the respective variables are also high showing that the variables are spread widely. The dispersion of the respective variables surrounding the mean is not low given that difference between the minimum and maximum values are high. The standard deviation of the data in relation to their respective means each had lower value than their mean except livestock. This shows that their volatility is low but high for livestock

The unit root method used was Phillips Perron. Table shows that all the variables were stationary at second difference. Given that the variables are integrated of order two, data was differenced to make it suitable for testing the hypotheses.

The coefficient of correlation at 0.132 point to a low linear relationship between credit to foodstock sector and agriculture insurance claims paid. At 0.157 there is a low linear relationship between credit to food-stock sector and agriculture insurance general reserves. 0.395 point to low linear relationship between credit to livestock sector and agriculture insurance claims. At 0.481 there is a low linear relationship between credit to livestock sector and agriculture insurance general reserves.

The adjusted coefficient of determination value of -0.064332 shows that the CFSS $=\mathrm{f}$ (AICP) model is capable of explaining only 6.43 percent of the variation in credit to food-stock sector. At --0.056655 the CFSS $=\mathrm{f}$ (AIGR) model can explain only 5.66percent of the variation in credit to food-stock sector. With a value of 0.171251 the CLSS $=\mathrm{f}$ (AICP) model can explain only 17.12 percent of the variation in credit to livestock sector. At 0.233821 the CLSS $=\mathrm{f}$ (AIGR) is capable of explaining only 23.83 percent of the variation in livestock sector.

The regression equation from Table4 is derived as CFSS $=5133966+0.000541 \mathrm{AICP}$ 
It is seen that the regression coefficient is positive. It shows that an agriculture insurance claim paid has a positive relationship with the volume of credit to foodstock sector. Therefore, one percent change in agriculture insurance claims paid will increase credit to foodstock sector by 0.0541 percent. The standard error of 0.001169 shows coefficient estimates as reliable given that there is very low noise in the estimates. It shows that the observations are close to the fitted regression line. However, p-value at 0.6518 is higher than the level of significance. In line with the decision rule the null hypothesis is upheld. It is concluded that agriculture insurance claims paid have no significantly effect on the volume of credit to foodstock sector.

The regression equation from Table 5 is derived as CFSS $=5024475.0+0.000145$ AIGR

It is seen that the regression coefficient is positive. It shows that an agriculture insurance reserve has a positive relationship with credit to foodstock sector. Therefore, one percent change in agriculture insurance reserves will increase credit to foodstock sector by 0.0145 percent. The standard error of 0.000264 shows coefficient estimates as reliable given that there is very low noise in the estimates. It shows that the observations are close to the fitted regression line. However, p-value at 0.5921 is higher than the level of significance. In line with the decision rule the null hypothesis is upheld. It is concluded that agriculture insurance claims paid have no significantly effect on the volume of credit to foodstock sector. Therefore, the null hypothesis is taken. It is concluded that agriculture insurance reserves have no significantly effect on the volume of credit to foodstock sector.

The regression equation from Table 4 is derived as CLSS $=873502.3+0.000844$ AICP

It is seen that the regression coefficient is positive. It shows that agriculture insurance claims paid have a positive relationship with credit to livestock sector. Therefore, one percent change in agriculture insurance claims paid will increase credit to livestock sector by 0.0844 percent. The standard error of 0.000439 shows coefficient estimates as reliable given that there is very low noise in the estimates. It shows that the observations are close to the fitted regression line. However, p-value at 0.0789 is higher than the level of significance. In line with the decision rule the null hypothesis is upheld. It is concluded that agriculture insurance claims paid did not significantly affect credit to livestock sector.

The regression equation from Table 4 is derived as CLSS $=735931.6+0.000214$ AIGR

It is seen that the regression coefficient is positive. It shows that agriculture insurance general reserve has a positive relationship with credit to livestock sector. Therefore, one percent change in agriculture insurance claims paid will increase credit to livestock sector by 0.0214 percent. The standard error of $9.58 \mathrm{E}-05$ shows coefficient estimates as reliable given that there is very low noise in the estimates. It shows that the observations are close to the fitted regression line. However, p-value at 0.0457 is higher than the level of significance. In line with the decision rule the null hypothesis is upheld. It is concluded that agriculture insurance general reserve have no significantly effect on the volume of credit to livestock sector. 


\section{DISCUSSION}

The regression coefficients were positive for the hypotheses test. The positive coefficient recorded in all hypotheses tests show that agriculture insurance claims paid and reserves have direct effect on the volume of credit to foodstock and livestock sector of the farming community in Nigeria. That is to say agriculture insurance claims paid and reserves increases the size of credit to foodstock and livestock sector of the farming community in Nigeria.

On the other hand, the insignificance recorded in all hypotheses tested shows that the magnitude of effect of agriculture insurance claims paid and reserves on the volume of credit to foodstock and livestock sector. It establishes that agriculture insurance in Nigeria has low effect on credit to foodstock and livestock sector of the farming community. The insignificance recorded suggests that agriculture insurance industry has not reached out to a wide berth of farmers. The spread of their coverage is limited to a few farmers. The volume of farmers to whom claims were paid in Southeastern Nigeria between 2008 and 2016 attest to this.

From Table 8 it is seen that a total of 185 farmers were paid for various claims by NAIC. This is despite the multitude of challenges that farmers in that region face. It goes to show that the patronage of NAIC is low. In extension to Nigeria the results of the study further establish that availability of Nigerian Agriculture insurance scheme is not significantly considered in giving out loans to farmers in the country.

\section{CONCLUSION}

Based on the findings of the study it is concluded that agriculture insurance has minimal effect on the volume of credit given to farmers. As such, agriculture insurance still has a long way to go to become relevant in the economy. In relation to its prospects, agriculture insurance low patronage also equates to an untapped market in the economy. Nigeria has huge agricultural potentials. It has an arable land potential of 98.3million ha consisting of 72.2 million ha (72.4 percent) cultivable (about 23 percent of arable land across all the West Africa) and only 27.1 million ha (27.6 percent) non cultivable land (Adebayo \& Olagunju, 2015). Agriculture still remains the largest sector of the Nigerian economy and employs two-thirds of the entire labour force (Food and Agriculture Organisation, FAO, 2019).

It is recommended that the capacity of the private sector to participate in agriculture insurance should be built up by developing a public-private partnership that incentivizes and supports companies to develop innovative products and services for agriculture. This will allow the private sector to offset the challenge of initial set up costs. Also, Pilot processes should be used to gradually grow farmers into participation in agriculture insurance. This will scale up farmers understanding of and trust in agriculture insurance. Industries should set up an ongoing yield data collection framework, using private data collection agents that execute crop cutting experiments to build a timely and cost efficient data collection process. This will boost agriculture insurance underwriting.

Journal of the Faculty of Agriculture and Veterinary Medicine, Imo State University Owerri website: $w w w$ ajol.info 


\section{REFERENCES}

Abugri, S., Amikuzuno, J.\& Daadi, E. (2017). Looking out for a better mitigation strategy: smallholder farmers' willingness to pay for drought-index crop insurance premium in the Northern Region of Ghana. Agricultureand Food Security, 6: 71.

Adebayo, O. \& Olagunju, K. (2015). Impact of Agricultural innovation on improved livelihood and productivity outcomes among small holder farmers in Rural Nigeria. A paper prepared for presentation at the 5th MSM Annual Research conference. Managing African Agriculture: Markets, Linkages and Rural Economic Development. $4^{\text {th }}$ September. MSM, Maastrichi. The Netherlands.

Akintunde, O.K. (2015). Determinants of Poultry Farmers' Participation in Livestock Insurance in Southwest Nigeria. Asian Journal of Poultry Science, 9: 233-241.

Bhattamishra, R. \& Barrett, C. B. (2010). Community Based Risk Management Arrangements: A Review. World Development, 38 (7): 923-32

EconomicTimes (2019). Definition of Market Development. Retrieved from www.economictimes.com on March 25, 2019

Eze, J. (2019). Enhancing Agricultural Value Chain. Retrieved from www.thisdaylive.com on March 25, 2019

Food and Agriculture Organisation (2019). Nigeria at a glance. Retrieved from www.fao.org on March 12, 2019

Governments of New Brunswick (2019). Agricultural Insurance. Retrieved from www2.gnb.ca on March 25, 2019

Hatch, D. (2008). Agricultural Insurance A powerful tool for governments and farmers. Retrieved from www.repiica.iica.int on March 25, 2019

Hansen, J., Hellin, J. \& Goslinga, R. (2016). A roadmap for evidence-based insurance development for Nigeria's farmers. CGIAR Research Program on Climate Change, Agriculture and Food Security (CCAFS), Working Paper No. 218

Hellin, J. \& Hansen, J. (2017). Building Agricultural Resilience through Insurance in Nigeria. Retrieved from www.reliefweb.int on March 25, 2017

Kuhn, S. (2016). Innovations and Emerging Trends in Agricultural Insurance. Retrieved from www.giz.de on March 25, 2019

McCarthy, N., Swallow, B., Kirk, M. \& Hazell, P. B. R. (1999). Property Rights, Risk, and Livestock Development in Africa. Washington DC: International Food Policy Research Institute.

Mordi, O. (1995). Element of Insurance. Enugu, University Press

Journal of the Faculty of Agriculture and Veterinary Medicine, Imo State University Owerri

website: www ajol.info 
Nnadi, F. N., Chikaire, J., Echetama, J. A., Iheanacho, R. A., Umuronakwa, P. C., \& Utazi, C. O. (2013). Agricultural Insurance: A Strategic Tool for Climate Change Adaptation. I (1) 1 9.

Ntukamazina, N., Onwonga, R., Sommer, R., Rubyogo, J., Mukankusi, C., Mburu, J.\& Kariuki, R. (2017). Index-based agricultural insurance products: challenges, opportunities and prospects for uptake in sub-Sahara Africa.Journal of Agriculture and Rural Development in the Tropics and Subtropics, 118(2); 171-185

Ogwo, Eche, Ibeabuchi, Nwite \& Enwereuzo (2000). Introduction to Insurance. Enugu, Immaculate Publication Nigeria Ltd.

Olubiyo, S. (2009). Econometric analysis of the impact of agricultural insurance on farming systems in the middle belt, Nigeria. African Journal of Food, Agriculture, Nutrition and Development, 9(6); 1407-1418

Onuk, E., Girei, A.,\& Aster, M. (2016). Determinants of crop farmer's participation in agricultural insurance scheme in Abuja, Nigeria.Merit Research Journal of Agricultural Science and Soil Sciences, 4(8);89-93

PremiumTimes (2018). Nigerian farmers refuse to repay N60 billion loan - Bank of Agriculture. Retrieved fromwww.premiumtimesng.comon March 25, 2019

Spacey, J. (2017). 6 Types of Market Development. Retrieved from www.simplicable.com on March 25, 2019

Valgren, V. N. (1930).*Address delivered to U. S. Department of Agriculture, on invitation of the Committee on Program; published at the request of members attending the meeting.

Zyka, E. \& Tomori, E. M (2014). Factors affecting the Insurance Sector Development: Evidence from Albania. The Romanian Journal, 51, 171 -188. 
Journal of Agriculture and Food Sciences Volume 17 Number 1, April 2019 pp 123 - 135

Table 1 Descriptive statistics

\section{CLAIMS FOODSTOCK LIVESTOCK RESERVES}

\begin{tabular}{lcccc}
\cline { 2 - 5 } Mean & $4.75 \mathrm{E}+08$ & 5390861. & 1274102. & $2.52 \mathrm{E}+09$ \\
Median & $5.47 \mathrm{E}+08$ & 5453110. & 1237440. & $3.63 \mathrm{E}+09$ \\
Maximum & $1.09 \mathrm{E}+09$ & 8039640. & 2342247. & $3.87 \mathrm{E}+09$ \\
Minimum & 78373013 & 3533430. & 353487.3 & $1.89 \mathrm{E}+08$ \\
Std. Dev. & $3.52 \mathrm{E}+08$ & 1437927. & 612581.8 & $1.55 \mathrm{E}+09$ \\
Skewness & 0.055222 & 0.131594 & 0.039811 & -0.589065 \\
Kurtosis & 1.607250 & 2.009950 & 1.944744 & 1.455541 \\
Jarque-Bera & 1.138637 & 0.612189 & 0.653278 & 2.201116 \\
Probability & 0.565911 & 0.736317 & 0.721344 & 0.332685 \\
Sum & $6.65 \mathrm{E}+09$ & 75472060 & 17837433 & $3.53 \mathrm{E}+10$ \\
Sum Sq. Dev. & $1.61 \mathrm{E}+18$ & $2.69 \mathrm{E}+13$ & $4.88 \mathrm{E}+12$ & $3.13 \mathrm{E}+19$ \\
Observations & 14 & 14 & 14 & 14
\end{tabular}

Source: Author's calculation using Eviews 10

Table 2: Unit root test

\begin{tabular}{|l|l|l|l|l|}
\hline Variable & Calculated value & $\begin{array}{l}\text { Order of } \\
\text { Integration }\end{array}$ & \multicolumn{2}{l|}{ Test Critical value } \\
\hline Claims & -8.754146 & $1(2)$ & $1 \%$ level & -4.200056 \\
\hline & & & $5 \%$ level & -3.175352 \\
\hline Foodstock & & & $10 \%$ level & -2.728985 \\
\hline & & & $1 \%$ level & -4.200056 \\
\hline & & & $5 \%$ level & -3.175352 \\
\hline \multirow{2}{*}{ Livestock } & -7.294167 & $1(2)$ & $10 \%$ level & -2.728985 \\
\hline & -9.421177 & $1(2)$ & $1 \%$ level & -4.200056 \\
\hline
\end{tabular}

Journal of the Faculty of Agriculture and Veterinary Medicine, Imo State University Owerri website: www ajol.info 


\begin{tabular}{|l|l|l|l|l|}
\hline & & & $10 \%$ level & -2.728985 \\
\hline Reserves & -9.528803 & $1(2)$ & $1 \%$ level & -4.200056 \\
\hline & & & $5 \%$ level & -3.175352 \\
\hline & & & $10 \%$ level & -2.728985 \\
\hline
\end{tabular}

Source: Author's calculation using Eviews 10

Table 3 Result of Model Adequacy

\begin{tabular}{|c|c|c|c|c|}
\hline Model & $\begin{array}{l}\text { CFSS } \\
(\mathrm{AICP})\end{array}$ & $\begin{array}{l}\text { CFSS } \\
(\text { AIGR) }\end{array}$ & $\begin{array}{l}\text { CLSS } \\
(\mathrm{AICP})\end{array}$ & $\begin{array}{l}\text { CLSS } \\
(\text { AIGR })\end{array}$ \\
\hline $\mathrm{R}$ & 0.132 & 0.157 & 0.395 & 0.481 \\
\hline $\mathrm{AR}^{2}$ & -0.064332 & -0.056655 & 0.171251 & -0.112094 \\
\hline
\end{tabular}

Source: Author's calculation using Eviews 10

Where CFSS $=$ Credit to Foodstock sector

CLSS $=$ Credit to Livestock sector

AICP = Agriculture insurance claimspaid

AIGR = Agriculture insurance general reserves

Table 4: Result of Hypothesis one test

Variable Coefficient $\quad$ Std. Error t-Statistic Prob

\begin{tabular}{ccccc}
\hline \hline CLAIMS & 0.000541 & 0.001169 & 0.462850 & 0.6518 \\
C & 5133966. & 682089.5 & 7.526822 & 0.0000
\end{tabular}

Source: Author's calculation using Eviews 10 
Table 5 Result of Hypothesis two test

\begin{tabular}{ccccc} 
Variable & Coefficient & Std. Error & t-Statistic & Prob. \\
\hline \hline RESERVES & 0.000145 & 0.000264 & 0.550435 & 0.5921 \\
C & 5024475. & 774028.5 & 6.491330 & 0.0000
\end{tabular}

Source: Author's calculation using Eviews 10

Table 6 Result of Hypothesis three test

\begin{tabular}{ccccc} 
Variable & Coefficient & Std. Error & t-Statistic & Prob. \\
\hline \hline \multirow{2}{*}{ CLAIMS } & 0.000844 & 0.000439 & 1.919974 & 0.0789 \\
C & 873502.3 & 256413.8 & 3.406612 & 0.0052
\end{tabular}

Source: Author's calculation using Eviews 10

Table 7 Result of Hypothesis four test

\begin{tabular}{ccccc} 
Variable & Coefficient & Std. Error & t-Statistic & Prob. \\
\hline \hline RESERVES & 0.000214 & $9.58 \mathrm{E}-05$ & 2.228746 & 0.0457 \\
$\mathrm{C}$ & 735931.6 & 280790.8 & 2.620924 & 0.0223 \\
& $=$
\end{tabular}

Source: Author's calculation using Eviews 10 
Journal of Agriculture and Food Sciences Volume 17 Number 1, April 2019 pp $123-135$

Chizoba P. Ehiogu and Aneke Joseph ${ }^{135}$

Table 8: Distribution of claims paid to farmers in Southeastern Nigerian

\begin{tabular}{|c|c|c|c|c|c|c|c|c|c|}
\hline & 2008 & 2009 & 2010 & 2011 & 2012 & 2013 & 2014 & 2015 & 2016 \\
\hline IMO & 3 & 11 & 2 & 12 & 1 & 2 & 3 & 1 & 2 \\
\hline ABIA & - & 11 & 0 & 0 & 0 & 6 & 6 & 2 & 2 \\
\hline ENUGU & 7 & 12 & 8 & 1 & 3 & 3 & 3 & 0 & 5 \\
\hline ANAMBRA & - & 3 & 2 & 5 & 3 & 23 & 12 & 5 & 12 \\
\hline EBONYI & - & 4 & 1 & 3 & 1 & 2 & 1 & 1 & 1 \\
\hline TOTAL & 10 & 41 & 13 & 21 & 8 & 36 & 25 & 9 & 22 \\
\hline
\end{tabular}

Source: Nigerian Agricultural Insurance Corporation Claims Reports

Journal of the Faculty of Agriculture and Veterinary Medicine, Imo State University Owerri website: www ajol.info 